\title{
Den danske Fredsdelegations Rejse til Paris og London i 1919.
}

\section{Dagbcgsoptegnelser.}

Af H. P. H a n s e n.

Fredsdelegationen bestod af 4 Representanter for de fire store politiske Partier, Landstingsmand A l e $x$ a n cl er Foss for det konservative Folkeparti, Folketingsmand $\mathrm{N}$. Neerga ard for Venstre, davarende Forsvarsminister P. M u $\mathrm{ch}$ for det radikale Venstre og Landstingsmand C. V. B ra m s n for socialdemokraterne, de hidtilværende nordslesvigske Representanter for Sunderjylland, $H . \quad D$. K loppenborg-Skrumsager, Nis Nissen og H. P. H a nss e n, samt Redaktør Andreas Grau som Medlem af Mellemslesvigsk Udvalg, dertil Etat:raaderne $H$. N. A n dersen og E. Glü ckstadt som sarlig sagkyndige i økonomiske Spørgsmaal.

Efter at der paa et Par forberedende Møder i Ldenrigsministeriet var opnaaet Enighed om Behandlingen af det sonderjydske Sporgsmaal paa Fredskonferencen, fastsattes Afrejsen til Torsdag den 27. Februar 1919, Klokken 3 Eftermidlag. Til den fastsatte Til gik vi ombord i $\emptyset$. K.'s Motorskib $" F i o-$ nia«. Med dette skih skulde jeg i August Maaned 1:14 have foretaget en Rejse til sian, men da jeg en Maaneds Tid for var paa Baldersbark efter Indbydelse af Landstingsmand Holger Petersen for at modtage nyttige Vink vedrørende Rejsen, kom østerrigs Ul- 
timatum til Serbien, og dermed var jeg klar over, at Rejsen maatte opgives.

Etatsraad H. N. Andersen modtog os, hod os velkommen ombord, og anviste os selv vore Kahytter. Klokken 3 stod vi ud af Frihavnen. Mens vi gik op ad Wresund, gav Etatsraaden os Reglerne for Maaltiderne og anviste os vore Pladser ved Bordet. Ved $4^{1 / 2}$ Tiden passerede vi Kronborg. Det havde stormet stærkt i de foregaaende Dage, men nu var Stormen ved at lægge sig, og vi mærkede ikke videre til Søgangen, da vi stod ud i Kattegat.

Overrejsen var meget behagelig. Vi samledes til alvorlig Forhandling et Par Timer hver Formiddag og hver Eftermiddag og droftede indgaaende alle de Spørgsmaal, der efter vor Mening kunde komme til Forhandling paa Fredskonferencen.

Vi besluttede at rette en Henvendelse til den franske Presse straks efter vor Ankomst til Paris og udarbejdede en Fællesudtalelse, som fik følgende Ordlyd:

"Een danske Delegation repræsenterer de fire store Partier i den danske Rigsdag, de slesvigske Reprasentanter repræsenterer haade Nordslesvig og Mellemslesvig. Alle ser de paa Iasningen af det slesvigske Spnrgsmaal med samme (Xjne; det danske Folk er som andre Folk delt i politiske Partier med vidt forskellige Anskuelser om indre Spørgsmaal, men i denne Sag staal disse Partier enige. Delegationen er kommet for overfor Fredskonferencan at give Udtryk for denne Enighed nu, da det danske Folks Ønske om Genforening kan ventes virkeliggjort som Folge af de Allieredes Sejr.

Det falles (xnske, der samler det danske Folk i Kongeriget og i Slesvig, er, at den nye Granse skal drages i Overensstemmelse med Folkenes Selvbestemmelsesret paa Grundlag af.en fri Folkeafstemning. Vi onsker, at denne Afstemning for Nordslesvigs Vedkommende skal foregaa snarest muligt, efter at Jandet er rommet af tyske Trop- 
per, og at Nordslesvig skal betragtes som en llelhed ved Afstemningen.

I Flenshorg og de (rrige mellemslesvigske Distrikter, for hvis Vedkommende d:r overfor Konferencen af I)anmarks Repra'sentanter er fremsat (Inske om Afstemning, ansker vi, at denne Afstemning skal foregaa kommunevis, og at den skal finde Sted $x$ Uger efter at disse kgne er lommede for tyske Tropper. Naar vi onsker, at der skal vare en Frist, er det, for at det fornodne (Oplysningsarbejde kan foregan, men vi unsker, at Fristen ikke skal vare langere end dertil nodvendigt, da der i Befolkningen i disse Egne er et starkt thske om en snarlig .Ifgurelse af dens skabne.

Vi narer den fuldeste Tillid til, at Fredskonferencen vil sikre en Afgorelse af det slesvigske Spurgsmaal i Overensstemmelse med selvbestemmelsesretten, der for dette sporgsmaals Vedkommende allerede i $1 \times 66$ paa Frankrigs Initiativ er fastslaaet red F'agfredens Artikel 5. Sporgsmaalet ligger saa klart, at vi haaber paa en snarlig Afg(yrelse. Det vilde vare en stor Glade for de danske Slesvigere og for hele det danske Folk, om Beslutningen om Afstemningen i slesvig kunde blive taget allerede ved den forestaaende Præliminærifed, og Afstemningen finde Sted snarest muligt efter denne. Og vi haaber da, at Overdragelse til Danmark af de Egne, som i Henhold til Afstemningen matte blive genforenede med Danmark, vil kunne ske straks efter Afstemningen, uanset om ikke alle de Sporgsmaal, der andet Steds skal ordnes, til sin Tid er afgjorte.

Danmark onsker Genforeningen med alle, der tænker og foler Dansk, men onsker ikke at have indenfor sine Granser en samlet tysk Befolkning, der er stwrk nok til at skabe en tysk Irredentisme og bringe Brud paa den nationale Enhed, der har varet Danmarks Lykke.

$V i$ foler os forvissede om, at Fredskonferencen vil modtage disse vore "Insker med Velvilje."

Særlig indgaaende og omhyggeligt drøftede vi VæIgerforeningens Forslag til Afstemningsregler. Vi vedtog til Slut enstemmigt at tilstille Fredskonferencen følgende Forslag: 


\section{I.}

"Nordslesvig opfattes som en Helhed, hvis Befolkning ved at stemme med Ja eller Nej tilkendegiver, om den vil genforenes med Danmark.

I Flenshorg og de andre Distrikter i Mellemslesvig, hrorfra onske om Ifstemning flemkommer, finder sadan Afstemning sited kommunevis, sabledes at Afstemningen $i$ hivel enkelt Kommune tages som vejledende Girundlag ved Afgurelsen af liransen

II.

Stemmeret ved disse $\Lambda$ fstemninger faal alle over 20 Aar gamle Mirnd og Kvinder, hjemmehorende i Ifstemningsomraadet, som

a) er fort i Haderslev, Aabenra, sonderborg, Flensborg og Tonder Amterr,

b) eller har haft fast (Ophold inden for disse Amter siden den 1. Januar 1900.

(c) eller er fudt i de navnte Amter, men udrist af de hidtilvalende Mymligheder.

III.

Stemmeretten udwres skiftligrt undar Former, der sikrer hrer enkelts frie Viljesytring. Myndighederne maa ikke we nogen Indflydelse paa Afstemningen. Fuhver stemmer i den fommune, hror han hal hjemme, de udviste $\mathrm{i}$ den Kommune, hror de ved Ldvisningen havde hjemme.

IV.

Afstemningsommadet maa, for Afstamningen foretages, vere rommet af de tyske Tropper, for Flenshorgs og de "vrige mellemslesvigske Distrikters Vedkommende mindst 8 t'ger for Afstemningen samtidig med Rrmningen indsattes der en blandet lommission, som er ndrustet med tilstrakkelige Magtmidler til Ht surge for, at Oplysningsarbejdet kan foregan frit og uforstyret, sad at en retfardig Afst: mning kan finde sted. Da de hidtilvarende Forvaltningsmyndigheder i stor lidstralining moles med Mistillid af den danske Befolkning, hemyndiges den blandede Kommission til fua Begaring af mindst 20 Vaxlgere i Landkommuner og Amtsdistrikter, mindst $2(N)$ Var]g"re $i$ Kredse, at fratage disse For altuingsmyndigheder den udwente Magt og insdarte en anclen i stedet. 
V.

IIos den danske Befolkning i Flensborg og Mellemslesvig og i vids Kledse af Befolkningen i Nordslesvig findes den (opfattelse, at det er nudventigt, at Flensholg og de mellemslesvigske Afstemningsdistrikter besattes af allielede eller neutrale Tropuer mindst i Iger, for Afstemningen finder sited."

De okonomiske sporgsmaal droftedes ligeledes indgaaende, og det vedtoges at fremsatte folgende Cdtalrlse overfor Fredskonferencen:

"I det (Ojeblik, l'rincipperne for det danske Slesvigs Tilbagegivelse til Danmark skal fastsattes, hliver det nodvendigt at traffe en ordning af do finansielle Forhold, som knytter sig rertil.

Canmark el af den Mening. at det vilde vare nuelfardigt, hvis det ved Inkorporationen skulde komme til at haje $t \mathrm{n}$ Del af de l!hye Idgifter, som den prewasisks Militarisme har jaalagt den danske Befolkning i stesvig. Der er jo i virkeligheden ingen Trivl om, at disse lidgifter ikke har skaht moduktive Vardier i deunn Provins, sum trartimod i de forlobne Aar har mattet betale whyre Skatter for at bidrage til opretholdelsen af det presssiske Regimente.

Danmark er altsaa af den Mening, at det vilde vare en retfordig ordniug af det finansielle spongmaul at fastsarte, at del skal tilhagebetales Tyskland en Del af de is Mill., som loanmark moltog i 186i.s som det Belob, der reprasenterede dets Kvota-Andel i Landets stmlede statsgarld paa det Tidspunkt, saaledes at denne Del sattes $i$ Forhold til dels den Folkemaengde, dels det landomraade, som vender tillage til Danmark Dog maa der til denne Sum larges Vardien af de Stataktiver, som de Territorier. der skal inkorporeles, hal erhvervet siden $1864 . \Lambda \mathrm{k}$ tiver af rent militar Natur bor dog i alle Tilfaclde ikke indhefattes deri.

(Werfor de samlede Krav, der kan stilles i Wverensstemmelse med det folegarende, on hvis endelige Fastsatlelse hor underkastes Ifgorelse af en hrotil af de allierede og assorierede Magters Fredskonference nedsat Kommission, kan Danmark paa sin side stille de betydelige Foldringer, det har paa Tyskland, Fordringer, som sand- 
synligvis langt overstiger det Beløb, som Danmark paa sin Side vil have at betale. De hidrorer vasentlig fra folkeretsstridige Hamllinger fla Tysklands side."

Endelig droftedes Optionen og de dermed i Forbindelse staaende For'lold.

For at undgaa Minefaren løb vi op med Norges Kyst til Højde af Bergen, gik derfra over imod New- castle, ned med den engelske Kyst, kastede sondag Eftermidalag Anker ved Themsens Munding og naaede Mandag Formiddag Klokken 10 til B o u log ne.

Undervejs havde vi daglig modtaget traadlose Telegrammer og var derigennem underrettet om Ldviklingen af den Ministerkrise, der $i$ disse Dage var udbrudt hjemme i Danmark. Etatsraaden val den furste paa Dxkket om Morgenen, stadig i godt Lune og meget underholdende. Samværet ombord var meget behageligt. Der var rig Lejlighed til at drofte alle Tidens bræendende Sporgsmaal, og der var megen Sagkundskab repræsenteret i Fredsclelegationen.

Da vi ankom til Boulogne, var det Regnvejr. Vi matte ligge $i$ Havnen til Klokken 2 og spiste endnu vor sidste Frokost ombord, for vi forlod vort herlige Skib, der skulde videre til Colombo efter Kopra. I Havnen var alt idel Travlhed. Iet vrimlede med kincsiske Kulier, der var ansat som Havnearbejdere. da Franskmændene laa ved Fronten. Klokken 3 afgik Iltoget til Paris. Ier blev stillet tre Kupeer til Fredsdelegationens Raadighed. Rejsen gik over Amiens, hvor vi saa stærke Spor af Kampen, nedskudte Bygninger og Tusinder af Granathuller udover Markerne paa begge sicler af Banen.

Ien 3. Marts Klokken 8 Aften ankom vi til Paris, hvor vi paa Banegaarden blev modtaget af den dan- 
ske Gesandt, Kammerherre $B$ e $r$ nh of t, hele den danske Legation, Professor Verrier, H. V. C I a use n og flere. Vi blev indlogerede i tre Hoteller. De to Etatsraader i Hotel Meurice, de danske Parlamentarikere og Andreas Grau i Hotel Cotinental, Kloppenborg-Skrumsager, Nis Nissen, Fuldmægtig Laage Petersen fra Udenrigsministeriet, som ledsagede Delegationen, og jeg i Hotel Deux Mondes. Vi udsendte Henvendelsen til den franske Presse og mødtes efter Aftale i Etatsraad Andersens Salon i Hotel Meurice Klokken $9 \%$ Aften.

Forhandlingerne begyndte med, at Kammerherre B e r $n$ h of $\mathrm{t}$ afgav en Beretning om Sagens Stilling.Den 21. Februar havde han i Overensstemmelse med Udenrigsministeriets Instruktion, som atter var i Overensstemmelse med Vælgerforeningens Resolution af 17. November 1918, ført Sagen frem for den belgiske Kommission. Direktør L a r o c h e i det franske Udenrigsministerium havde Dagen efter Forhandlingerne sagt: "Den danske Fremstilling var Arligheden og Redeligheden selv«. Amerikanerne havde været særdeles velunderrettede, men havde erklæret sig cnige med os, hvad ligeledes Englænderne havde gjort. $P$ ic llon og $T$ a rdie u reprasenterede Frankrig $\mathbf{i}$ Kommissionen. Tardieu var sarlig indflydelsesrig og syntes ligeledes at være enig med os. Japanelne og Italienerne havde derimod ikke udtalt sig endnu. Amerikanerne havde erklaret, at Grænserne matte sattes saaledes, at der ikke skabtes nye Irredentaer. Efter at Forhandlingerne var sluttet, havde Pichon spurgt, om ingen wnskede yderligere Oplysninger.

L a nsing havde spurgt, hvorledes vi havde tankt os Ordenens Opretholdelse, naar Tropperne tog 
port. Efter at dette Sporgsmaal var besvaret, havde Lansing endvidere spurgt, om vi havde tronkt os, at Slesvig vilde blive givet tilbage uden de tyske skattebyrder. Dette Sporgsmaal var blevet hesvaret med Ja. Lansing havde endelig spurgt: "Vil dette ikke være en stærk Opfordring til Tyskerue om at stemme dansk? I) Dernast havde han spurgt om Fristerne. Det var af Kommissionen blevet antydet, at det maatte betragtes som onskeligt, at der fastsattes en 6 Maaneders Frist, inden Afstemningen fandt Sted i Mellemslesvig, og ligeledes, at Landet blev rommet for tyske Tropper $i$ et Balte sydfor Afstemningslinien.

Fredspræliminarerne, fortsatte Bernhoft, vil blive fastsat 12 Dage fra l)ato i Trier. Kommissarerne, som skal lede Afstemningen, vil blive udnevnt af Fredskonferencen.

Til disse Meddelelser af Kammerherren sluttede sig en livlig Droftelse. Delegationen opfordrede ham efter tidligere Aftale til at vare dens Ordforer overfor Kommissionen og til $i$ denne Egenskab at ordne en Sammenkomst med den, samt soge at skaffe sig Underretning om, hvilke Sporgsmaal, Kommissionen især kunde onske besvaret. Delegationens naste Møde blev fastsat til Tirsdag den 4. Marts, Klokken 3 Eftermiddag.

Tirsdag den 4. Marts 1919.

Tilstede var i Etatsraad Andersens Salon Klokken 3 Eftermiddag hele Delegationen, Kammeiherre Bernhoft og Magister H. V. Clausen.

Kammerherren meddelte, at Kommissionen vilde modtage Delegationen Torsdag den (i. Marts, Klokken 10 Formiddag, i Udenrigsministeriet. Det havde end- 
nu ikke været ham muligt at faa oplyst, livilke Spørgsmaal der vilde blive Delegationen forelagt, men han vilde fortsætte sine Bestrabelser. Vi droftede derefter endnu en Gang Punkt for Punkt de vedtagne Afstemningsregler, soln paany iblev godkendt. Etatsraad Andersen havde enclnu ikke faaet Forbindelse med Englænderne og Anterikanerne, men vilde fortsæette sine Bestræbelser. Næste Mode fastsattes til Onsdag den 5. Marts Klokken 3 Eftermiddag i Etatsraad Andersens Salon.

Onsdag den 5. Marts 1919.

Delegationen, Kammerherre Beluhoft og $H . V$. Clausen samledes son aftalt. Belnhoft meddelte, at han havde talt med de amerikanske Medlemmer af Konmissionen. De fandt ikke, at der var Grund til at afgive en ny Fremstilling af Sporgsmaalet. Det kunde betragtes som afgjort, at der blev Afstemining i begge Omraader. Man onskede srerlig Oplysning om Fristernes Længde og om Besættelsen af Landet.

A lexander Foss meddelte i Tilslutning dertil, at han havde haft Lejlighed til at tale nied et andet Medlem af Kommissionen, som havde spurgt, om Danmark var interesseret i, at Svenske og Nordmænd fik Sæde i den Kommission, der skulde lede Afstemningen, og endvidere, luvorfor man ikke fra dansk Sirle onskede Afstemning helt ned til Slien. Dertil havde han svaret, at der ikke var frenkommet Onsker fra Eefolkningens side syd for den af Bernhoft dragne Afstemningslinje. Skulde Befolkningen i Sydslesvig afstemme, vilde det desuden efter hans Mening affode en for de nordligere Distrikter skadelig tysk Agitation. Vedkommende havde desuden talt om Afstemningsregleme og billiget, at Besæet- 
telsen ikke omfattede Slesvig By. Han havde ytret, at man næppe vilde sende Tropper, men nojes med at sende et Par Krigsskibe. Alexander Foss havde benyttet Lejligheden til ogsaa at bringe det finansielle Spørgsmaal paa Tale. Der var ikke blevet indvendt noget imod, at man tog Statsgælden fra $181 i 4$ som Udgangspunkt, men man havde henvist til, at dette Spørgsmaal vilde blive overvist til Finanskommissionen.

Etatsraad H. N. A n dersen meddelte, at han havde varat i Forbindelse med Englænderne, hvem han i Forvejen under et Ophold i England havde overgivet et af C'denrigsministeriet udarbejdet Memorandum. De onskede den Gang, at vi vilde gaa længere imcd syd ned mod Kanalen og til Gengreld for, at vi var blevet skaanet for Krigens Rxdsler, overtage en Del Byrder her. Han havde oplyst, at dette vilde være farligt for Danmark og hævdet, at Danmark som Kanal-Vogter vilde blive en Skuffelse for de Allierede. Fra engelsk Side gik man nu, som han havde kunnet konstatere, ud fra de Synspunkter, som Kammeiherre Bernhoft havde gjort gældende overfor Kommissionen.

Dr. Munch tog bestemt Afstand fra enhver Tanke om at udstrække Afstemningsomraadet til Dannevirke-Slien. Dertil bemarkede Etatsraad A nd e r s e n, at der endnu var Understromninger tilstede, som stilede længere syd paa, men at han dog havile faaet det bestemte Indtryk, at Afgcrelsen vilde falde i Overensstemmelse med de af Kammerherre Bernhoft fremsatte Onsker.

Ne e r a a rd: Den nationale Enhed, som hidtil har vieret Danmarks Styrke, maa absolut ikke brydes. Dette maa vi bestemt hapve. 
Dr. M n n h oplæste et Udkast til de Udtalelser, som Kammerherre Bernhoft efter Delegationens Ønske og paa dens Vegne skulde fremsætte overfor Kommissionen. Udkastet blev, hvad Indholdet angik, godkendt af Delegationen, mens Kammerherren selvfolgelig kunde bruge den Form, som han fandt mest passende.

Etatsraad An dersen: Vor Hovedopgave maa nu være at underbygge Kammerherrens Udtalelser og at styrke hans Autoritet, saa det staar klart for alle, at han har hele Nationen bag sig.

Det vedtoges endnu, at vi den folgende Søndag skulde paa en Biltur til Reims og muligvis tillige til Noyon.

Torsdag den (i. Marts 1919.

Efter Aftale modte hele Delegationen Klokken 9,40 i Hotel Meurice, hvor der holdt 3 Biler, som hurtigt forte os til det franske Udenrigsministerium. Vi kørte ind i Gaarden, hvor Vognene gjorde Holdt, gik derpaa op ad Trapperne og blev vist ind i et Par Ventesale, som var meget pragtfuldt udstyret, alt var holdt i rodt og Guld.

Efter at have ventet et Kvarters Tid blev vi af en Adjudant ført ind i Forhandlingssalen til den saakaldte belgiske Kommission. Det var en lang, smal Sal med et hesteskoformet Bord. Midt foran Tvierbordet præsiderede $\mathrm{Tard}$ i e $\mathrm{u}$ med Amerikaneren, Professor Haskins paa sin højre og Englænderen, Sir E y r e C r o w e paa sin venstre Side. Ved Siden af sir Eyre Crowe sad det andet engelske Medlem af Kommissionen, Professor $\mathrm{H}$ e a d l a m Morley. Ved hajre Side af Professor Haskins sad det andet amerikanke Medlem, S. I). E m b i ck. Paa venstre Side 
af Bordet sad Direktoren i det franske Udenrigsministerium, Laroche, to Japanere og en Belgier, paa højre Side to Italienere. Tilstede var endvidere soln Sekretær Englænderen C a r n e gi e.

Kammerherre $\mathrm{B}$ er $\mathrm{n}$ h of $\mathrm{t}$ forestillede os enkeltvis, inden Forhandlingerne begyndte, og Tardieu gav os alle Haanden, før vi satte os. Vi fik Plads anvist mellem begge Længdeborde. I forste Række sad Bernhoft og Munch, derefter Foss og Neergaard, H. P. Hanssen og Etatsraad Andersen, Bramsnæs og Kloppenborg-Skrumsager, H. V. Clausen og Glückstadt, Nis Nissen og Andreas Grau.

Før Forhandlingerne aabnedes, tog Tardieu et Cigaretfoderal frem og bød de nærmestsiddende en Cigaret, selv tændte han ogsaa en. Derpaa fik Kanmerherre Bernhoft Ordet for at afgive den aftalte Beretning, i hvilken han konstaterede Rigsdagens og. den tilstedeværende Delegations fuldstændige Enighed med Hensyn til de Synspunkter, der i Modet den 21. Februar var blevet gjort gældende overfor Kommissionen.

Der rettedes derpaa af Kommissionen en Dol Sporgsmaal til os, som forekom mig meget forstandige, og som viste, at Kommissionen havde indgaaende Kendskab til Sagen. Mens vi svarede, var der mange Par kloge, forskende $\emptyset$ jne rettede mod os. Sarlig interesseret var aabenbart Amerikaneren Professor $\mathrm{H}$ a s k in s, som ojensynlig var godt inde i Forholdene. Da vi saaledes helt uforberedt under Droft:1sen af Afstemningsreglerne motiverede Forslaget om at fatsatte Fristen for Bosættelse i Afstemningsomraadet til den 1. Januar 1900 med Henvisning til Voldspolitikken, spurgte han straks: "Hvorfor 1900, 
Kollerpolitikken begyndte jo dog 1898«. Vi maatle saa forklare, at Udvisningerne fortsattes i de forste Aar, og at der forst kunde regnes med en deraf iølgende Indvandring fra 1900 . Ogsaa $\mathrm{L}$ a roc h e, titulær Minister og Direktør i det franske Udenrigsministerium, lagde under Forhandlingerne indgaaende Kendskab til Forholdene for Dagen. Mange af Spørgsmaalene blev rettede til mig. Laroche spurgte især om Mindretallenes Stilling, da dette var et principielt set meget vigtigt Spørgsmaal med Henblik paa de mange svævende nationale spørgsmaal. Han spurgte specielt, hvilke Garantier Danmark kunde byde med Hensyn til den fremtidige Behandling af et eventuelt tysk Mindretal indenfor Rigets Grænser. A le x a n d e F F s svarede: "De Garantier, der ligger i Danmarks frie Forfatning og frisindede Lovgivning, særlig hvad Kirke- og Skolespørgsmaal angaar.« Spørgsmaalet blev derefter udsat, idet vi blev opfordret til at præcisere dette nærmere $\mathbf{j}$ en skriftlig Erklæring. Det samme var Tilfældet ned Optionsspørgsmaalet. Vi blev ligeledes, hvad det angik, efter en kort Drøftelse opfordret til at fremsætte et skriftligt Forslag. Da Forhandlingerne slutterle, gav Tardieu os alle Haanden til Afsked.

Klokken 1 var en Del af os indbudt til Frokost hos Bernhoft. Tilstede var af Delegationen: Alexander Foss, Neergaard, Kloppenborg-Skrumsager, Nis .Nissen og jeg, endvidere Formanden for Senatets udenrigske Udvalg, Vicomte de Cornudet, Direktør Laroche, Magister H. V. Clausen, Professor Verrier og Franz von Jessen.

Efter Frokosten kom Neeryaard og Clausen i Samtale om fransk Kunst. Jeg afbrød dem og bad, 
da jeg ikke selv taler Fransk, Neergaard om at indlede en Santale med Laroche om Forholdene i Nordslesvig. Dette gjorde han. Jeg blev ogsaa draget ind i Samtalen, idet Franz von Jessen kom til og tilbød sig som Tolk. Vi drøftede derfor Forholdene ret indgaaende, og Laroche billigede, saavidt vi kunde skonne, i det hele vore Synspunkter og gik blandt andet, som Mellemslesvigsk Udvalg ønskede, ind paa at afkorte den oprindeligt paatænkte if Maaneders Frist mellem Afstemningerne i Nordslesvig og Mellemslesvig.

Om Aftenen var jeg indbudt til Middag hos Franzvon Jessen, som boer i en køn lille Villa i Udkanten af Byen. Tilstede var endvidere: Alexander Foss, Neergaard, Direktor Prior og Forfatteren Johs. Jørgensen. Franz von Jessens nydelige lille franske Soldaterbarn, som han havde taget til sig, efter at Faderen var falden, sang for os. Samtalen var meget livlig. Franz von Jessen rettede stærke Angreb paa Regeringen og ligeledes paa den saakaldte Oktoberadresse. Da han under Angrebene citerede Udtalelser af den tidligere franske Gesandt i København, Conty, og tog hans Parti overfor Professor Høffding. med hvem Gesandten havde haft et Sammenstad, greb Alexander Foss ind og sagde hvast, at af de to Mænd foretrak han Høffding, idet han tilføjede en meget skarp Bemærkning om Conty. Neergaard sluttede sig til Alexander Foss og tog ligeledes Professor Høffdings Parti.

Franz von Jessen overgav Neergaard Kopier af to vigtige Telegrammer, som under Krigen fra Paris var blevet afsendt til ham og Etatsraad Andersen, men som de ikke havde modtaget. Han troede, at Tele- 
grammerne var blevet undertrykt af Censuren. Neergaard vilde undersoge dette nærmere. Baade Franz von Jessen og Prior hævdede, at Regeringen var meget daarligt anskrevet i Frankrig. Johs. Jørgensen stemte i med og stadfæstede dette.

Fredag, den 7. Marts 1919.

Om Formiddagen aflagde Madame de Quirielle, (Jaques de Coussange) mig en Visit paa mit Hotel. Vi talte ene sammen i en Timestid; hun var meget elskværdig og medgørlig. Hun sagde, at saavidt hun kunde se, var ingen fremstaaende dansk Politiker Tilhænger af Dannevirkelinien. Dette stadfæstede jeg.

Alexander Foss, Neergaard og Dr. Munch aflagde imens en Visit hos Udenrigsminister Pich on, som de fandt meget velvillig stemt. Han havde ytret, at han fandt de danske Krav meget moderate, men at han meget vel forstod onsket om at bevare Nationalstaten og at blive fri for tyske Elementer i storre Antal indenfor Rigets Grænser.

Klokken (i Eftermiddag havde Delegationen en Sammenkomst, hvor vi affattede og enstemmig godkendte følgende Beretning om Forhandlingerne med den belgiske Kommission den 6. Marts:

"Kommissionens ordforer udtaler forst, at det, man onsker, er at gore forskellige spurgsmaal.

G esandten oplæser I'dtalelsen paa Delegationens Vegne.

Ordfareren: Er alle enige om ciræusen for det egentlige Nordslesvig? Der svares ja.

Ordforeren: Fr der ogsaa Enighed om Gransen for Afstemningsomraadet i Mellemslesvig?

rie s a $d$ t e $n$ : Ja, denne Grænse gaal saa langt mod Syd, at der længere mod syd slet intet cirundlag er for danske Stemninger. 
O ld a o re $\mathrm{n}$ : "Naar onskes Afstemningen i Nordslesvig"? Srar: Uden Frist, saasnart Afguralsen er faldet. „Ja, men Evakuationen tager ogsaa Tid." Ja, vel 8 Dage. w)g Valglisterne og lignende." Swar: Man kan sige 14 Dage ialt

Ordforeren: "Narr onskes Afstemning i Mellemslesrig?" $\&$ Uger efter Romningen. "Men der skal ogsaa livist til Rımningen.» Ja, navnlig i Flensborg, vel en 14 Dage. Den samlede Tid angives da til 10) Uger. Selve lismuingen behover nemlig ikke mere Tid i Mellemslesvig, men Agitationen krover nogen Tid. De tyske Tropper i Flensborg opgives til 400\%.

Ordforelen spurgte om det whonomiske Mellemvarende. Den udarbejdede Erkluring oplastes () ruforeren siger, at det horer ikke under denne liommission; han anbefaler at sende den til honferencens Præsident med Anmodning om Forelangels for det finansielle I'lvalg.

() rdforeren sponger om Optionslegler. Det narnes, at man onsker gensidig Optionslet i to Aar, at alle, fodt i det Omraale, der kommer til Eanmark, vil kunne optere fol Danmark; alle, der har hjemme i dette (Mmlaade, for Tyskland; de opterende skal tage Boparl i det land, de valger; fast Ejendom kan bevares i dot andet land, Lasore indfores toldfrit, de bor beskyttes mod skattepaalarg ved lidrandringen. liedegnrelse loves.

Afstemningsregleme oplases af Gesandten. Man standser ved forskellige runkter.

Den a merikanske Delegerede: „Afstemningens Friked betyder vel hemmelig $\Lambda$ fstemning?" Ja.

Den amerikanske Delegerede: "Hvorfor (ivansen red 1900, ikke ved 1898, da kollerpolitikken begyndte? Srar: Kollerpolitikkens storre Betydning fra 19(H). Grundkoh, Subrentioner, Udrisning af Tjenestefolk, Indrandringen til Flenslorg, desuden Flaadestationer i Flenshorg og sonderbory.

Len a merikanske Delegarede: Ja, det er tilstrakkelig Begrundelse, simrger dog, om der ar Tal for Indvandringen. "Nej.»

Med Hensyn til Rumningen spurges, om der onskis homning kun i Afstemningsomraadet eller ud derover. Ler stares: en haly snes hilometer sydligere for at undgat Rirningel's "Fr del Tropper der?" Nej, men det bur 
hindres, at der kommer. Derved forsvinder jo ogsaa Arbejder-og Soldaterraadenes Indflydelse.

() r d f re re $\mathrm{n}$ : "Er det unskeligt, at Forvaltningen i Slesvig By fjernes?" Efter Konference med Hanssen og de andre Sonderjyder svares, at der intet Onske er derom, det kan snarest volde Vanskeligheder, idet Socialdemokraterne vil blive ophidsede ved Oplosningen af Alhejder-og soldaterraadene.

1) rdf øreren sporger, om det ikke er bedre, at de tyske Myndigheder fjernes $i$ hele Afstemningsomraadet $i$ Stedet for kun de Steder, Juror det forlanges. Efter Konference med Sonderjyderne svares: Nej; det viıker ophidsende, der mangler Personer. Nogle Steder kan der sart.tes danske Kontrollurer. Der spmiges om Antallet af Stemmesteder i Mellemslesvig, svares 141. Der naves den Mulighed, hvor Personer savmes, at tage dem fra Nordslesvig; i Flensborg navmes Adrokat Ravn som Tilforordnet; det tilfojes, at Personsporgsmalet kan droftes med den clanske Regering.

() rdf" reren sporger, hvorledes man tanker sig den militare ordning. Der er en vis Modsigelse mellem Afstemningsreglernes sidste Funkt og den ()pfattelse, der her lial vajet fremme, siger han. Vi svarer, at der i Dele af Befolkningen, som angivet i vedkommende lunkt, er en Tro paa, at Besattelse vil vise sig nodvendig, men at vi antager, som det fremgaar af Motiverne til Afstemningsreglerne, at det vil vare tilstrakkeligt, at der er ef eller flere (Mrlogsskibe paa Flensborg Fjord, hvorfra der i givet Tilfalde vil kunne landsattes et Detachement. Ordfol'eren sporger, hvormange det da skulde vare. Der navnes, at f. Eks. $j(x)$ vikle vare tilstrarkkeligt.

() rdf "re ren spurger: (Inskel man, at der i den Handede Kommission, der skal lede Afstemningen, er danske og tyske Rrprasentanter. Siar: Dor lagges ikke Vaget paa, at de ev Medlemmer af liommissionen, men der hro vare saadanne som radigivende Sagkyndige.

") r f gr e le $n$ sparger, om man i den blandede Kommission, ved Siden af de allierede Repra'sentantel, onsker Norske og svenske. Der svares Ja.

Under Diskussionen herom fremhaves fra vor side: stiwkt det unskelige $i$, at det hele afgures ved Præliminarfreden, og at Iandet straks efter Afstemningen overgaal til Danmark. Da dette begrundes med Rekvisitio- 
nerne, svarer (Ordforeren, at disse horer jo op meil Evakuationen. Vi svaler hertil, at Befolkningen ansker meget snart at faa sine Forbold ordnede, og at det er unskeligt, at den danske Forfatning, der skal andres, hurtigt kommer i orden. Ordfureren sjulger da, om det kan ske, naar Nordslesvig er overleveret, for Mellemslesvig kommer: Ja, det, der bliver tilbage, bliver Valglovssporg:maal, de kan tages for sig.

Ordforeren sporger, om man tanker sig fiarantier for de tyske Minoriteter, og det f l a nske lidenrigsministeriums Rejusentant i den be :g is k $\mathrm{K}$ om mission gol opmærksom paa, at det har Interesse af Hensyn til Kongressens almindelige Grundsatninger. Vi svarer, at sadanne liarantier formentlig ikke er nodvendige, der twnkes anvendt samme Love som i Danmark; der er Undervisningsfrihed; del vil kun!̣? blive $\mathrm{i}$ alt Fald private Skoler med tysk Sprog. Den almindelige danske Lovgivning vil antagelig vare tilstiolikelig Garanti. Det navnes, at Danske syd for Cransen bor behandles tilsvarende, men vi undgaar at stille c'et op som en Tanke om gensidig Forpligtelse og fremsatter folgelig intet Onske om at faa det fastslaaet i Aftalerne. Vi lover skriftligt at præcisere (Opfattelsen med Hensyn til Garantier for Minoriteterne.«

Jeg var i Forvejen blevet opfordret til at udarbejde et Udkast til det Forslag om Optionsreglernes Affattelse, som Kommissionen havde ønsket. Jeg forelagde og motiverede nu Forslaget, der blev vedtaget en bloc, blandt andet med den vigtige Bestemmelse, at de efter den 1. Oktober 1918 tilflyttede Personer - hvorimellem der var mange tvivlsomme Elementer - kun skulde have dansk Indfødsret efter særlig Bevilling. Forslaget havde følgende ordlyd :

"Retten til at optere i Lobet af 2 Aar efter Afstemningen bliver gensidig anerkendt.

Enhver, der er fodt i den Del af silesvig, som tilbage. gives til Danmark, har Ret til at optere for Danmark. 
Enhver, der er bosat i den Del af Slesvig, som kommer tilbage til Danmark, har Ret til at optere for Tyskland.

Faderens Option gerlder ogsaa for lans Bern under 18 Aar.

De Personer, som efter 1. (Oktober 1918 har bosat sig i den Del af slesvig, som kommer tilbage til Danmark, kan ikke opnaa Indfodsret uden sirelig Tilladelse.

Optanterne skal tage Bopal i den Stat, for hvilken de har opteret. Det vil staa dem frit for at bevare deres Ejendomme, som er beliggende i den stat, hvor de for (Optionen var hosat. De faar Rot til at indfore deres Lasore toldfrit i det Land, for hvilket de har opteret. De skal have Lov til at medtage deres Formue til Trods for Udfor'selsforlud og uden at erlarge de Afgifter, der rammer Formuen ved Uafor'selen.

Aftenen tilbragte vi som sxdvanlig sammen. Vi var under Opholdet i Paris skiftevis Gæster i hinandens Saloner.

Efter Forslag af Alexander Foss besluttede vi derefter at besvare Kommissionens Sporgsmaal vedrorende Garantier for Behandlingen af eventuelle tyske Mindretal saaledes:

"I Besvarelsen af et Spolgsmaal, der blev stillet af Kommissionens Formand, har de danske Delegerede den Ere at meddele fulgende:

De Delegerede er enige om, at Foreningen af det danske Slesvig med hongeriget bor foregaa saaledes, at alle den danske Stats fremtidige Borgere behandles efter de samme liberale og demokratiske Principper og skal nyde de samme lettigheder. Heraf folger saalerles, at de tyske Mindretals naturlige het til at hruge deres eget sprog bliver respekteret. De Delegerede konstaterer navnlig, at den frie skole er et P'rincip, som altid er blevet fulgt i den danske Lovgivning."

Lørdag den 8. Marts 1919.

Om Eftermiddagen var Etatsraaderne Andersen og Glückstadt, Alexander Foss, Neergaard og jeg in- 
viteret til The hos Franz von Jessen sammen med Chefredaktøren for "Le Temps", H e r b e t t e. Forinden aflagde Dr. Munch, Neergaard og jeg en Visit hos Formanden for Deputeretkammerets Udvalg for udenrigske Anliggender, Franklin Bouillon, en meget ilter Herre. Han fandt til at begynde med vore Krav altfor moderate og reftede i Forbindelse hermed overordentlig stærke Angreb paa Tyskerne. Ingen Tysker, sagde han, maatte $\mathbf{i}$ de første Menneskealdre sætte sin Fod paa fransk Jord. De var Forbrydere og Spedalske. Her greb Neergaard ind og bemarkede tort, at ud fra de synspunkter, han her gjorde gældende, maatte han antagelig kunne forstaa, at vi Danske ikke ønskede at faa et større Antal Tyskere indenfor Rigets Grænser, men foretrak at bevare Nationalstaten. Denne Bemærkning faldt i god Jord. Han Jo, gned sig i Hænderne og sagde, at det kunde han forstaa. Men da vi saa fortalte ham, at vi vilde til Soissons og Reims for at se Ødelæggelsens Vederstyggelighed med egne (xjne, fik han et nyt Raserianfald og sluttede med: "Det er rigtigt, at De tager derud, De vil saa med egne (犭jne kunne overbevise Dem om, at disse Barbarer har forvandlet store Dele af Nordfrankrig til en Ørken. Men de skal bøde for deres Skændselsgerninger«, og atter udstıdte han de frygteligste Trusler.

$V$ i blev opholdt langere af ham, end vi havde ventet, og Neergaard og jeg fik en Chauffor, der ikke var lokalkendt, da vi vilde kare videre ud til Franz von Jessen. Vi ankom derfor med henved en Times Forsinkelse. Det ovrige Selskab var allerede samlet. H e r b e t t e drog mig straks ind i en livlig Samtale. Han talte godt Tysk, og vi forte derfor L'nderholdnin- 
gen paa dette Sprog. Efter at have rettet nogle Spørgsmaal vedrørende Nordslesvig spurgte han mig indgaaende om Stemningerne og Stromningerne i Tyskland. Han onskede at vide, om der var stark Stemning for Oprettelsen af et selvstændigt SlesvigHolsten, af et selvstændigt Hannover, og oul der var andre partikularistiske Strømninger i Tyskland. Jeg udtalte, at saavel i Hertugdømmerne som i Hannover fandtes der for Tiden ret stærke partikularistiske stromninger, og at Welferne i Hannover siden 1867 uafbrudt havde været repræsenteret i Rigsdagen.

Hvad Sonderjylland angik, fandt Herbette ogsaa, at vi var mere moderate med vore Fordringer, end de Allierede i Grunden onskede. Men, tilføjede han med et fint Smil, "vi gaar ved Bedømmelsen af disse Forhold vel nok for meget ud fra vore egne Interesser. Jeg finder, at Deres Standpunkt, som maa dikteres af danske Interesser, set fra dette Synspunkt, maa betegnes som rigtigt."

Ved vor Sammenkomst havde Franz von Jessen meddelt mig, at der var komnet en Telefonmeddelelse til mig fra Kammerherre Bernhoft om, at jeg skulde møde ham paa Quai d'Orsay ved Porten lige overfor Invalidebanegaarden Klokken 6,55, da Direktør L a roche i Udenrigsministeriet onskede Oplysninger om forskellige Forhold af ham, H. V. Clausen og mig.

Da jeg ikke var stedkendt i Paris, og Tiden var knap, tilbød Johs. Jørgensen, som deltog i Sammenkomsten hos Franz von Jessen, at ledsage mig derhen, et Tilbud, som jeg modtog ned Tak.

U'denfor Udenrigsministeriet var der samlet en stor Folkemængde, Kommissærerne havde lige af- 
sluttet deres Arbejdsdag, og Bilerne kom i hurtig Rækkefølge ud af Gaarden. Kammerherre Bernhoft kom sammen med H. V. Clausen, og lige som vi vilde gaa ind ad Porten, kørte Marschal Foch forbi i sin Bil. Bernhoft gjorde mig opmerksom paa ham. Vi gik op i et Venteværelse, hvor vi traf den serbiske (iesandt, som Bernhoft forestillede for os. Da Bernhoft ytrede: "Nu faar vi meget snart vor Sag ordnet i Overensstemmelse med vore Ønsker «, udbrød Serberen med et dybtfølt Hjertesuk: "Ak, kunde jeg bare sige det samme for Serbiens Vedkommende."

Han blev først kaldt ind. Vi maatte vente imens, og Klokken blev henved $7^{\prime}$, f for vi kom ind. Vi forhandlede derefter $i$ en Times Tid med Laroche. Han sad ved et Skrivebord, der var fyldt med Papirer, og bad os tage Plads i tre Lænestole, som var hensat ved det. Derpaa tog han et maskinskrevet Aktstykke paa en halv snes Foliosider frem og begyndte at give os nogle Meddelelser.

"Kommissionens Indstilling er nu fardig", sagde han, "men jeg onsker endnu at drøfte et og andet med Dem, inden jeg afgiver den. Kommissionen har besluttet at drage Romningslinien sydom Slesvig By«. Om den videre Forhandling nedskrev Kammerherre Bernhoft, H. V. Clausen og jeg i Fallesskab en Beretning i Venteværelset umiddelbart efter, at Forhandlingerne var sluttet. Denne Beretning lod med enkelte Tilfojelser efter Hukommelse saaledes:

"Vi har besluttet", sagdle Laroche indledende, "at Overpræsidenten, Regeringspræsidenten, Landraaderne, Overborgmestrene etc. skal romme Landet nordfor Romningslinien, inden Afstemningen finder 
Sted." Dette "etc." ønskede vi fjernet og i Stedet for noje angivet de Myndigheder, der tidligere var Uduvere af Politimyndigheden«. Jeg foreslog Politimiesteren (2. Borgmester) i Flensborg, Borgmestrene og Amtsforstanderne. Dette blev indfxjet. "Soldaterraadene skal oploses«, fortsatte han, nog de Medlemmer af dem, der ikke har hjemme i Nordslesvig, skal roinme Landet, ligeledes Medlemmer, som er hjemmehørende i Nordslesvig, men er traadt i Funktion efter den 1. Marts 1919. Nye Arbejder- og Soldaterraad maa ikke oprettes«. Han oplæste derefter Afstemningsreglerne, som i alt vesentligt falder sammen med vort Forslag. Stemmeret faar herefter:

a. alle, som er fodt og bosat i Afstemningsomraadet. b. alle, som har været bosiddende i det før den 1. Januar 1919;

c. alle, som er blevet udvist af de hidtilvarende Myndigheder.

Efter mit Forslag, som jeg motiverede med en Lenvisning til dem, der var gaaet over Grænsen under Krigen, noterede han yderligere:

d. alle, som har taget midlertidigt Ophold i Danmark under Krigen, men er hjemmehorende i Afstemningsomraadet.

Der skal stemmes i Kommunerne. Udtrykkene Nordaslesvig og Mellemslesvig bruges ikke, da de ikke er præcise nok. Men det nordslesvigske Afstemningsomraade gaar til den af Vælgerforeningen fastsatte Linie og det mellemslesvigske Afstemningsomraade derfra ned til den af Kammerherre Bernhoft fastsatte Græuse for dette Omraade. 
Laroche ønskede derefter at drøfte Optionssporgsmaalet med os. Der er fastsat en 2 Aars Frist at regne fra Afstemningsdagen. Alle, som bor i det afstaaede Omraade, kan optere for Tyskland. Alle, som er fodt i det afstaaede Omraade, men opholder sig udenfor dette, kan optere for Danmark. Overflytning af Løsøre kan ske som foreslaaet. Faderens Option er gyldig for Børn under 18 Aar. Personer, som har bosat sig i Afstemningsomraadet efter den 1. Oktober 1918, kan ikke faa dansk Indfødsret uden ved særlig Bevilling. Optanterne skal bosætte sig i den Stat, for hvilken de har opteret. Det staar dem frit for at bevare deres faste Ejendom i den stat, hvori de har haft Ophold for Optionen. De kan tage deres Formue med sig ud af Tyskland uden at betale særlige Skatter eller Afgifter.

Rømningen af Tropper og civile Myndigheder skal finde Sted senest 10 Dage efter, at Præliminærfreden er undertegnet. Afstemningen i Nordslesvig skal foretages senest 3 Uger efter Rømningen. Straks efter Bekendtgørelsen af Afstemningens Udfald og inden Fastsættelsen af den endelige Grænse er I)anmark berettiget til at besætte Nordslesvig med sine civile og militære Myndigheder.

I Mellemslesvig finder Afstemningen Sted 5 I'ger efter Afstemningen i Nordslesvig. Grænsen fastsættes af de Allierede efter Indstilling af den Internationale Kommission, hvis Forslag bestemmes af Afstemningen under Hensyntagen til økonomiske og geografiske Forhold (Vandløb, Veje, Baner). Naar Grænsen i sine Hovedtræk er fastsat af de Allierede, men forinden den er udstukket i Marken, er llanmark berettiget til at besætte det Omraade, som til- 
deles det, med sine civile og nilitære Myndigheder. Samtidig vil Tyskland atter kunne besætte det rømmede Omraade. Tyskland afstaar derefter alle sine Suverænitets-Rettigheder i det afstaaede Omraade til Danmark.

Kommissionen skal bestaa af 3 Allierede, et norsk og et svensk Medlem. Den vil faa danske og tyske Raadgivere og skal træde i Funktion samtidig med, at Romningen tinder sted.

Jeg forsøgte at faa indføjet en Bestemmelse om, at de nye Øvrighedspersoner skulde udnævnes efter Forslag fra dansk nordslesvigsk side. Men dertil svarede Laroche, at man ikke onskede dette, da noget lignende $i$ saa Fald maatte gælde for Tyskerne for de tysktalende Distrikters Vedkonmende, men at der selvfølgelig vilde blive taget vidtgaaende Hensyn til de danske Raadgiveres Forslag."

Efter at Beretningen var nedskrevet, gik vi hver til sit. Kammerherre Bernhoft vilde endnu samme Aften afsende en Chifferdepeche til Kobenlıavn. $H$. V. Clausen gik hjem, og jeg tog ene tilbage til Hotellet. Vi var alle tre meget opromte og tilfredse, fordi vore Ønsker var blevet opfyldt. Da jeg kom til Hotellet, var Klokken godt 9. Neergaard, Branınces, Professor Verrier, Kloppenborg-Skrumsager, Nis Nissen, Andreas Grau og Lützhöft Nielsen - som var Privatsekretær hos Alexander Foss - sad endnu ved Aftensbordet, men vilde lige rejse sig. Da jeg meddelte Resultatet, blev der almindelig Glade. Vi trak os tilbage til vor Salon. Neergaard forlangte Champagne og talte, henvendt til Ver'ier, for Frankrig. "At man dog skulde opleve det! At man dog skulde opleve det!«, blev han ved med at gentage. 
"Jeg var 10 Aar, da Ulykken brød ind over os i $186 i 4$ og har folt den dybt og smerteligt. At man dog skulde opleve det!« Jeg talte for Professor Verrier, Nis Nissen for Elsass Lothringen. Stemningen var hoj.

Sondag, den 9. Marts 1919.

Biltur over Soissons og Reims. Jeg tog min Rejsekappe paa og satte mig foran hos Chaufføren for bedre at kunne nyde Udsigten. Vi var 4 Biler i Folge, Delegationen fuldtallig paa Etatsraaderne Andersen og Glückstadt nær, Harald Scavenius med Frue, H. V. Clausen med Frue og Direktør Prior. Vi startede Klokken 7 Morgen. Vejret var graat, en Tid lang taaget, Landskabet smukt. Det varede ikke længe, før vi saa de første Spor af Krigen. Forst Skyttegrave, Lejre, Artilleristillinger, saa nedbrudte Huse. Markerne var næsten overalt tilsaaet med Vintersæd og saa godt ud. Vi mødte Soldater alle Vegne, ogsaa mange farvede Tropper. Amerikanerne var stærkt repræsenteret. Efterhaanden som vi nærmede os Soissons, blev Sporene af Kampen tydeligere, mange Krigergrave og Dækninger udgravet i Vejkanterne, nedskudte og splintrede Træer, lange Rækker af skyttegrave, Granater, Patronkasser og Patroner i Titusindvis struet ud langs Vejene og meget mere viste, hvor Kampen havde raset. Vi naaede Soissons Klokken $10^{1} / 2$ og spadserede hen til Kirken, som tydelig nok havde været Skive for Artilleriet og nasten var helt odelagt. Hele Kvarteret omkring Kirken var en Ruinhob, Byen var ode, der stod endnu $k$ un ganske enkelte Huse, deriblandt et Hotel, hvor vi spiste Frokost i et Værelse, der har synlige Spor af Kampen. Saa gik det videre efter Reims. Et Par 
Steder undervejs gjorde vi Holdt ved Slagmarker og Lejrpladser. Vi samlede Hjælme, Vaaben og Patroner op, som endnu laa paa Valpladserne i Massevis. Jeg tog blandt andet en Gasmaske med mig, men glemte den uheldigvis senere paa Hotellet i Epernay. Reims mindede mig om Pompeji - en dod By - for Krigen havde den 115,000 Indbyggere, nu knap 5060. Kirken var meget ramponeret. Der var rømmet et smalt Spor henad Gaden, til begge Sider laa alt $\mathbf{j}$ Ruiner. Mellem disse Ruinhobe kørte vi atter ud af Byen. Vognene skulde have fort os tilbage til Paris igen, men Klokken var bleven mange, og Chaufiorerne erklærede, at det var for sent, og at der bestod strenge Forskrifter. Vi blev da enige om at køre ned til Epernay og tage med Toget Klokken 7 derfra. I Epernay, hvor vi havde en god Times Ophold, spiste vi til Middag og rejste saa Klokken 7 tilbage til Paris, som vi naaede ved 10 Tiden. Iet havde været en meget bevæget og indholdsrig Dag.

Mandag, den 10. Marts 1919.

Om Formiddagen tog Dr. Munch og jeg hen til Direktøren for Krigsfangevæsenet, hvor vi efter Aftale traf Professor Verrier. Vi vilde forhandle med Direktøren om de sønderjydske Krigsfanger for snarest muligt at faa dem hjemsendt. Vi blev vel modtagne. Direktoren var flink og imødekommende. Niu da Grænsen for Afstemningsomraadet kunde betragtes som fastlagt, vilde Hjemsendelsen snart kunno begynde. Det vilde gaa hurtigst, hvis Clemenceau dekreterede, at Fangerne skulde hjemsendes. Efter Aftale med mig havde Professor Verrier allerede et Par Dage for indgivet en Rapport til Clemenceau og i den foreslaaet, at alle i Afstemningsomraadet hjem. 
mehørende Fanger skulde sendes hjem saa tidligt, at de kunde deltage i Afstemningen. Vi meddelte Direktøren dette, og han raadede os derefter til personligt at søge Foretræde hos Clemenceau og foredrage ham Sagen. Skønt der næppe vilde være Udsigt til, at han kunde modtage os, da hans Tid var uhyre stærkt optaget, telefonerede Direktøren derhen for at aahne os Vejen. Generaladjudanten svarede, at Clemenceau ikke var tilstede, men at han allerede liavde læst Profesor Verriers Rapport og paa den skrevet. De t ske saaledes. Sagen kunde dermed betragtes som ordnet.

Da vi tog bort fra Direktøren, besluttede vi at fortsætte vore Eestræbelser for hurtigst muligt at fida Fangerne hjem. Professor Verrier mente, at de burde sendes hjem med et fransk Krigsskib. Han havde allerede bragt dette i Forslag paa ledende Sted, og hans Forslag var blevet modtaget med Velvilje, selv vilde han i saa Fald ledsage Fangerne. Da vi efter Hjemkomsten aflagde Beretning og droftede sag?n med Delegationen, mente Etatsraad Andersen imidlertid, at dette vilde gaa for langsomt. Han tilboul at sende "Russia" til Frankrig efter Fangerne og Delrgationen, hvis sagen kunde ordnes saa hurtigt, at vi kunde føre Fangerne med os hjem.

Klokken 1 var Delegationen indbudt til Froko;t hos Prins Georgaf Grækenland. Paa Alexander Foss og Bramsnæs nær, som var optaget af Forreininger, havde vi alle modtaget Indbydelsen. Vi kørte derhen i 3 Biler med Etatsraad Andersen i Spidsen. Prinsen boede i en Villa udenfor Byen, som Prinsessen, fodt Bonaparte, havde arvet efter sine Forældre. Prinsen, en høj, rank Mand med kraftige 
Ansigtstræk, jævn og ligefrem i sin Optræden taler korrekt Dansk. Han modtog os paa Trappen. Vi blev ført ind $i$ en Salon med tilstødende Arbejdsværelse og straks inddraget i en livlig Samtale. Det viste sig, at Prinsessen, som har tilbragt sin Barndom og Ungdom i Frankrig og senere i en Aarrække levet med sin Mand paa Kreta, til vor Forbavselse ogsaa talte Dansk, omend ikke fuldt saa korrekt. Hun tog Plads i en Sofa mellem Dr. Munch og Nis Nissen og førte en meget livlig Samtale med dem. Klokken $1^{1 / 2}$ gik vi til Bords. Prinsessen sad mellem Etatsraad Andersen og Dr. Munch, Prinsen mellem Neergaard og mig. Ved Bordet fortalte Prinsen os mange Træk fra Kreta. "Politikerne«, sagde han, "er. der, som alle Vegne, Llykken, - Danmark selvfolgelig undtaget«, tilfojele lian og bukkede smilende for os. Han fortalte, at han sammen med Kong Christian X havde været ombord paa "Dannebrog" udenfor Kolding Fjord, da Krigen udbrød. De havde da droftet Krigens eventuelle Udfald, og han havde udtalt Ønsket om, at han, naar Freden blev sluttet, maatte kunne ride ind i Sonderjylland. Dette vilde nu, haabede han, gaa i Opfyldelse.

Efter Frokosten kom jeg i livlig Samtale med Prinsessen, som viste sig meget interesseret $\mathbf{i}$ sønderjydske og danske Forhold og rettede mange Sporgsmaal til mig. Santalen gled ind paa sønderjydernes Deltagelse i Krigen. Da hun hørte, at Nis Nissen havde været med, opfordrede hun ham til at fortalle hende noget on sine Oplevelser.

Etatsraad Andersen betegnede sig selv som hjemme i Huset og var det ajensynlig ogsaa. Han blev modtaget og behandlet som en kær gammel Slæegt- 
ning. Børnene, en Søn og en Datter, sunde og kraitige Børn, som saa opvakte ud, kom ind og hilste og var tydeligt nok fra tidligere Tid velkendt med Etatsraaden. Hvad der glædede os alle, var at modtage et stærkt Indtryk af Prinseparrets varme Følelse overfor Danmark, som gav sig Udtryk paa mangfoldige Maader, ikke mindst $i$ deres indgaaende Kendskab til det danske Sprog og danske Forhold i det hele taget.

Klokken $7^{1 / 2}$ var jeg indbudt til Middag hos Kammerherre B e $\mathbf{r} \mathbf{n}$ of $\mathbf{t}$. Tilstede var af Delegationen: Etatsraaderne Andersen og Glückstadt samt Dr. Munch, endvidere den norske Gesandt, Baron WedelJarlsberg, den svenske Gesandts Frue, Grevinde Ehrensvärd, Legationsraad Engelsted og Frue og en Slægtning af Kammerherren. Efter Bordet gik Samtalen meget livligt. Den norske Gesandt var vel underrettet og meget underholilende. Overfor mig roste han Kammerherre Bernhoft i høje Toner. "Han dèr har Mod, ser De«, sagde han, idet han pegede paa Kammerherren. Der blev talt meget om den tyske Spionage, Tyskernes Færd i Amerika og deres Grusomheder i Belgien, som havde vakt en uhyre Forbitrelse i Frankrig. Tyskerhadet slog os under Opholdet i Paris i Møde alle Vegne. Det var dybt, og man sagde, at det vilde blive varigt. Men Tiden vil vel ogsaa her vise sig som den store Læge. Etatsraad Andersen talte med mig om Kobet af en Ejendom ved Alssund. Vi blev enige om Ønskeligheden af at afholde et Forhandlingsmøde, hvortil hele Delegationen skulde indkaldes, den næste Dags Formiddag. 
Tirsdag, den 11. Marts 1919.

Vi samledes om Formiddagen i Hotel Meurice, udvekslede Meninger og aflagde Beretninger. Det blev besluttet, at vi skulde gøre et alvorligt Forsøg paa at faa Krigsfangerne fra Afstemningsomraadet med os hjem. Etatsraad Andersen vilde i saa Fald lade "Russia gaa over efter os. Vi drøftede indgaaende de finansielle Spørgsmaal, som Etatsraaderne Andersen og Glückstadt vilde arbejde videre med. Før vi gik fra hinanden, oplæste Etatsraad Andersen et Brev fra den tidligere engelske Gesandt i Konstantinopel, som efter Paalæg af Bal fou $r$ indbod Delegationen til at være den engelske Regerings Gæster under Opholdet i London.

Vi 4 Sønderjyder var blevet indbudt til Middag. Klokken 8,15 paa Hotel Majestic af de engelske Medlemmer af den belgiske Kommission, men endvidere var vi indbudt til Aften hos Professor Verrier. Vi besluttede derfor at dele os, saaledes at Andreas Grau og jeg gik til Englænderne, Kloppenborg-Skrumsager og Nis Nissen derimod til Professor Verrier. Indbydelsen udgik fra $\mathrm{Headlam}$ Morley, fra hvem jeg modtog et længere Brev. Da hverken Andreas Grau eller jeg kunde tilstrækkeligt Engelsk til at føie en Samtale paa dette Sprog, hvor Ordene skulde vejes nøje, havde vi i Forvejen henstillet til Headlam Morley, om Samtalen ikke kunde føres paa Tysk, og vi havde faaet Meddelelse om, at der ikke var noget til Hinder herfor, da baade han og Sir E y re C. r ow e beherskede det tyske Sprog.

Vi blev i Hotel Majestic modtaget af Kriminalpolitiet. Hotellet er rent engelsk, her bor ogsaa Lloyd George og de øvrige engelske Statsmænd. Vi 
maatte i Forhallen gøre Rede for', hvad vi vilde, og lade vore Navne indføre $i$ en $B o g$, inden vi kunde gaa videre. Vi blev derefter modtaget af $\mathrm{Car}$ ne g i e, der havde fungeret som Sekretær den Dag, Delegationen mødte for Kommissionen. Senere kom Morley, en ældre, høj, mager Mand, noget sjusket i sin Paklædning, og Sir Eyre Crowe, som struttede ai Energi. Begge havde sjældent kloge Øjne. En fjerde Englienders Navn husker jeg ikke. Han blandede sig ikke i Samtalen og trak sig tilbage umiddelbart efter Middagen. Ved Bordet havde jeg Sir Eyre Crowe paa min højre og Headlam Morley paa min venstre Side. Andreas Grau sad med Morley paa sin højre og Carnegie paa sin venstre Side. Samtalen var meget livlig. Morley talte især med Grau om Dannevirke-Linjen og søgte at udforske, om der ikke var Nodsætninger tilstede, som Delegationen søgte at skjule, om der ikke var mange Danske, der vilde have Dannevirke-Linien, og om det ikke havde været rigtigere at udstrække Afstemningsomraadet dertil. Andreas Grau bestred dette under Henvisning til, at der ved Afstemningsomraadets Fastsæettelse var taget Hensyn til alle Ønker fra Befolkningens Side om at deltage i Afstemningen. Min Samtale med Sir Eyre Crowe var overordentlig interessant. Han udtalte sig meget aabent om alle Forhold. $\mathrm{Nu}$ og da indskød Morley en Bemærkning. Efter Bordet tog han livlig Del i Samtalen.

Sir Eyre Crowe forskede forst ligesom Herbette hos Franz von Jessen efter separatistiske Bevægelser i Tyskland. "Frankrig ser med Bekymring ud i Fremtiden", sagde han. "Vi skærer nu den preussiske Ørus Kløer meget stærkt tilbage, men vi ved, at 
de vil vokse ud igen. Hvor meget vi end svækker det tyske Rige ved Grænserne, borttager det dog ikke Frygten for, at Tyskland atter vil rejse sig og painy krinve Revanche. Vi maa derfor soge at svække Preussen ved at forebygge, at dets Overvægt indenfor Riget ogsaa fremtidig bliver bestemmende for Rigets Politik. Preussen vil blive svækket stærkt ved Pulens Genoprettelse. Det kan betragtes som afgjort, at Danzig vil tilfalde Polen, som vil blive stort og stærkt, og ligeledes at Nordslesvig vil tilfalde Danmaık. Men dette er ikke nok. Det maa betragtes som ønskeligt, at der udskilles særlige Stater af Preussen indenfor Rigets Grænser«. Dermed kom han ind paa Spørgsmaalet: Hvad er der af separatistiske Bevægelser i Tyskland. Jeg henviste til Welferne i Hannover, som lige siden 18177 uafbrudt har været repræsenteret $i$ den tyske Rigsdag, til slesvigHolstenerne, som atter kræver et selvstændigt SlesvigHolsten, og til de partikularistiske Bevægelser, der efter Sammenbruddet spores i Rhinlandene. De Oplysninger, jeg kunde give ham om disse Forhold, faldt øjensynlig $i$ god Jord. "Tyskerne maa nu undorskrive alt, hvad vi kræver«, var Omkvædet i hans Udtalelser, "men vore Krav bør være forstandige ogr lave en vis indre Berettigelse», tilføjede han.

Samtalen gled over paa den militære Situation. "Vi har oplevet frygtelige Tider" sagde han. "Førsic Gang i August 1914. Vi havde da ikke blot opgivel Kanalhavnene og Paris, men ogsaa Bordeaux. Alle Englands Tilførsler var i Tiden før Marneslaget indstillede paa Marseille. Vi troede ikke, før Marneslaget var slaaet, at Bordeaux kunde holdes. Anden Gang var under Foraarsoffensiven i 1918. Hvorfor 
gik Tyskeme ikke videre frem? Vejen var jo aabeı? Vi var sprængt fra hinanden. Det var frygtelige (jjeblikke. Tyskernes Gennembrud vilde selvfølgolig ikke have ændret Krigens endelige Udfald, men det vilde have udskudt Afgorelsen i Maaneder, maaske i Aar." Jeg henviste til, at Tyskernes Kræfter var ultømt, da de naaede Amiens, og gav et Referat df, hvad en preussisk General havde meddelt os $i$ den tyske Rigsdag om Aarsagen til, at Fremstødet var ebbet ud. Situationen var, sagde jeg, som naar et Par Brydere maa holde inde, fordi begges Kræfter er udtømt.

Ligesom de fleste andle fremstaaende Statimænd, som vi her kom i Beroring med, rettede ogsaa Sir Eyre Crowe voldsomme Angreb mod Tyskerne. Han fortalte mig, at hans egen Mor var tysk - en Søster til Admiral v. Holtzendorff - og at hans soster var gift i Berlin, - hende hørte han nu aldrig fra -, men Slægtskabsforholdet mildnede ikke lians haarde Dom. Tyskerne havde ovet utrolige Forbrydelser, sagde han, og Straffen vilde ikke udeblive. De anede endnu ikke, hvor omfattende et Materiale Englænderne sad inde med. I Amerika havde baade Bernstorff og Dernburg brugt Metoder, som trodsede enhver Beskrivelse. Materialet vilde senere blive offentliggjort, og saa vilde det tyske Folk maaske dog endelig faa Ojnene op. Da han omtalte Bernstorffs Virksomhed i Amerika, indskød jeg den Bemærkning, at Grev Bernstorff, efter hvad han selv havde meddelt mig under en Samtale $i$ det tyske Udenrigsministerium, havde været udset til Leder af den tyske Fredsdelegation. Dertil svarede Sir E!re Crowe, at dette viste, hvor lidt Tyskerne endnu for- 
stod deres stilling. Hvis han efter alt, hvad der var forefaldet i Amerika, var kommet til Paris som Leder af Fredsdelegationen, vilde han være blevet jaget ${ }_{1} d$ af Byen.

Jeg spurgte om Kejserens Skærbne. „Folket kræver ham udleveret og stillet for en Domstol", sagde han. "Personlig er jeg af den Mening, at en Kommission bør undersoge alt, fremlægge Akterne for Offentligheden og overlade den Dommen, og at der saa ikke bør foretages mere imod ham. Men jeg trol' ikke, at denne Opfattelse vil sejre. Folket kræver med stigende Styrke, at han skal stilles for en Krigsret og dømmes.«

Om Grev Brockdorff-Rantzau sagde han, at han var klogere end Grev Bernstorff, men at det var helt uforstaaeligt, at han sluttede sig til den nuvi-rende Regering. Dette viste tydeligt nok, at der ikke var Tale om en Systemforandring i Tysklands Udenrigspolitik. Derpaa tydede ogsaa Tysklands vedvarende Propaganda i Spanien. Rumænien og andre Lande. I Rumænien havde de Allierede i disse Dage opsnappet Flyveskrifter, som opfordrede til en bolsjevistisk Revolution. Paa enkelte Eksemplarer fandtes det osterrigske Udenrigsministeriums Stempel. Propagandaens Forbindelse med Tyskland var endnu ikke konstateret, men utvivlsomt tilstede. Det var skandaløst, at Tyskland saaledes vedvarende ødslede Millioner ud til den udenlandske Propaganda.

Fuldmægtig Laage-Petersen havde Dagen før meddelt Delegationen, at han under en Samtale med Englænderne havde faaet det Indtryk, at man fra Ententens Side paatænkte at ordne Sagen saaledes, 
at der maatte afsluttes en dansk-tysk Traktat vedrorende Afstaaelsen. Jeg spurgte under Henvisning hertil Sir Eyre Crowe, om der laa noget til Grund for denne Meddelelse. "Nej«, svarede han, "det kan der ikke være Tale om. Der foreligger Præcedens i Venetiens Afstaaelse til Frankrig. Sagen vil blive ordnet paa denne Vis. Der vil ganske vist foreligge en Række Enkeltheder, som maa ordnes, men som ikke kan optages i Fredstraktaten. Derfor vil det blive nødvendigt, at der nedsættes særlige Kommissioner, som ordner dem. Disse Kommisioners Nedsxttelse bestemmes i Fredstraktaten."

Efter Middagen hos Englænderne tog Andreas Grau og jeg ud til Professor Verrie r, hvor vi fandt et talrigt Selskab, deriblandt alle Delegationens ovrige Medlemmer. Verriers Hustru, Sønner og en Datter var tilstede. Modtagelsen var meget hjertelig. Jeg fik imidlertid ikke talt meget med ham ved denne Lejlighed, da Alexander Foss straks trak mig ind i Professorens Arbejdsværelse for at læse en Artikel om Kanalsporgsmaalet i "Le Temps for mig. Artiklen var tydeligt nok stærkt paavirket af min Samtale med Herbette hos Franz von Jessen. I Selskabet traf jeg atter Madame de Quirielle og vekslede nogle Ord med hende.

Onsdag, den 12. Marts 1919.

Da Fredsdelegationen for et Par Dage siden aflagde et Besøg i Versailles, kunde Alexander Foss, Neergaard og jeg ikke deltage i Turen, fordi vi var optaget af vigtige Forretninger. En dansk Mand, Kobmand Davidsen, havde nu stillet os $\sin$ Bil til Raadighed til en Tur til Versailles, som skulde foregaa i Dag. Neergaard blev imidlertid forlindret $i$ 
sidste Øjeblik, fordi han sammen med Dr. Munch skulde deltage i en Sammenkomst med Lord Robert Cecil for at drefte Danmarks stilling til Folkenes Folbund. Alexander Foss og jeg tog derfor ene afsted og havde en dejlig Tur. Vi korte gennem st. Cloud, saa Udsigten over Paris fra Terrassen og ankom til Versailles ved 10-Tiden, hvor vi horte, at slottet forst var aahent fra Klokken 1 . Vi spadserede da et Par Timer i den herlige Park, spiste derefter Frokost i Byen og besaa senere slottet. I)er var under alt dette rig Lejlighed til at udveksle Meninger om udenrigske og hjemlige politiske Fol hold. Jeg fandt Alexander Foss vel informeret paa alle Onraader. Vi kom hjem ved 4-Tiden. I'nder vor Fravarelse var Krigsfangesagen blevet fremmet videre. Der var blevet arrangeret en Visit hos en General, der havde med Fangevæesenet at gere, og jeg skulde have varet derhen sammen med Dr. Munch og Professor Verrier. Da Nis Nissen tog derhen i mit Sted, havde jeg dog ikke forsømt noget.

()m Aftenen gav Delegationen en Middag for Kammerherre Bernhoft, Legationsraad Engelsted med Frue, Pressechef Krabhe, H. V. Clausen med Frue, Franz von Jessen, den norske Gesandt Baron WedelJarlsherg, Professor Verrier og Frue, Hr. og Fru de Quirielle, Bankdirektør Prior - jeg husker i Øjeblikket ikke flere. -

Dr. Munch bud Velkommen og erklærede, at der ikke skulde holdes Taler. Den norske Gesandt tillod sig dog straks den Bemærkning, at det var meget trivlsomt, om dette Forbud vilde kunne overholdes. Senere brod han det og talte for Sonderjyderne og Sønderjylland. Jeg fulgte hans Eksempel og rette- 
de først en Tak til de nordiske Folk for den Sympati, de havde vist os, og som Taleren havde givet saa varmt Udtryk. Dernæst takkede jeg Kammerherre Bernhoft, til hvem jeg rettede nogle hjertelige og anerkendende Ord, og endelig rettede jeg en Tak til Frankrig og de tilstedeverende Franskmand, idet jeg sluttede med et: Leve Frankrig. Kort efter hævedes Bordet, men vi blev endnu liange sammen og havde det meget hyggeligt.

Torsdag, den 13. Marts 1919.

Opbrud fra Paris. Vi tog afsted ved Middagstid. Den danske Legation og andre Danske, deriblandt Franz von Jessen med sin lille Soldaterpige var modt paa Banegaarden for at tage Afsked med os. Vi fik overrakt Blomster, og jeg modtog som Gave fra Oberstinde Andersen en dejlig Silkefane. Vi kørte derefter i Pullmanvogn til Boulogne ad samme Vej, som vi var kommet til Paris, men denne Gang i straalende Solskin. Overfarten Boulogne-Folkestone gik let. Der var Mæengder af Officerer og uniformerede Damer ombord. Vi spadserede først paa Drkket, men da det blev koldt, bænkede vi os i Kahytterne, hvoraf to udelukkende var stillet til vor Disposition. Landgangen i Folkestone gik ligeledes glat. Vore Pas blev efterset og fundet rigtige. Derefter rejste vi videre i Pullmanvogne. Vi ankom til London ved 10-Tiden og blev modtaget paa Banegaarden af $\mathrm{Hr}$. Synge, en høj Embedsmand i Udenrigsministeriet, og af den danske Gesandt, Kammerherre C a s t e nsk i old, som forte os til Vogne, der stod rede til at kore os t:1 Carlton Hotel, hvor vi fik Varelser anviste. 
Fredag, den 14. Marts 1919.

Da vi om Morgenen kom ned fra vore Værelser, blev det meddelt os, at Regeringen havde stillet $3 \mathrm{Bi}$ ler til vor fri Disposition. Vi 4 Sonderjyder korte om Formiddagen en Tur ud gennem Byen og tilbage gennem Hyde Park. Derefter samledes Delegationen til en falles Frokost paa Carlton Hotel. Om Eftermiddagen foretog vi atter en Koretur, denne Gang forbi Tower, Parlamentet og rundt i Byen. Om Aftenen Klokken $7^{1 / 2}$ gav Etatsraad Andersen en Middag, hvortil foruden Delegationen Kammerherre Castenskiold og Direktor Madsen-Mygdal var indbudt. Ved Kaffen havde jeg en længere Samtale med Kammerhellelı, af hvem jeg fik et godt Indtryk.

\section{Lørdag, den 15. Marts 1919.}

Om Formiddagen kørte vi en Tur i Byen. Efter Frokost blev vi Klokken 1 modtaget $\mathrm{i}$ Udenrigsministeriet af Lord Curzon. Etatsraad Andersen, som tydeligt nok stod paa en neget fortrolig Fod med Lorden, fortalte mig bagefter, at han havde lært ham at kende for mange Aar siden, da han som ung Mand var kommet til Siam. Senere havde han truffet ham som Vicekonge i Indien. Lord Curzon er en høj, smuk Mand med et fint, glatraget Ansigt, let skaldet paa Issen med langt Haar strøget ned bag Ørerne og i Nakken. Mest paafaldende var hans rolige, forskende Øjne. Vi blev forestillede af Etatsraad Andersen. Han gav os alle Haanden og hilste os med et: How do you do. Dewefter satte vi os i en Rundkreds om hans Skrivehord, Etatsraaden nærmest i en Lanestol. Det meste af Tiden forte han Ordet. Lorden onskede os til Lykke med, at vi nu atter kom tilbage til Danmark. Vi bukkede og takkede. Efter 10 Minutters Forløb var 
Audiensen forbi - en engelsk Udenrigsminister har meget at gøre - og Lorden gav os atter Haanden til Afsked.

Vi kørte hjem til Hotellet, klædte os om og gik Klokken 3 med Etatsraad Andersen i spidsen t'l det kgl. Slot, hvor Dronning Alexandra vilde modtage os i Audiens.

I Forhallen blev vi modtaget af en xeldre Hofdame, som kunde tale lidt dansk, derpaa iom en meget gammel, krumbıjet Hofmand, stottende sig til en forsvarlig Stok. Han drog Etatsraad Andersen og Alexander Foss i Samtale. I Hallen var der opstillet Buster af Kong Christian IX og Dronning Louise. En hoj Officer, aldre Mand i Khakiuniforn og meget umilitarisk i sin Holdning sluttede sig til. Saa gik Turen til de indre Gemakker. Etatsraad Andersen blev forst kaldt ind, derpaa den danske Delegation og tilsidst vi 4 Sonderjyder. Jeg blev ved min Indtræden af Etatsraad Andersen forestillet for Dronningen, som drog mig ind $\mathrm{i}$ en Samtale om Forholdene. Hun var desværre meget tunghør, talte noget stivt med engelsk-tysk Akcent, men ellers korrekt Dansk og udtrykte sin store Glæde over, at vi kom tilbage til Danmark. Dronningen udtalte samtidig Haabet om, at Ejderen atter maatte blive Danmarks Grænse. Hendes varme Følelser og Troskab mod Danmark og hendes store Pietet overfor Forældrene og hele den kgl. Slægt var rørende. Mens jeg stod og talte med Dronningen, horte jeg gentagne (range Etatsraad Andersen sige til Prinsesse Victoria, der stod lige bag ved mig: "Nu maa De tale Dansk, Prinsesse Victoria, nu maa De tale Dansk, der er flere af Delegationen, som ikke kan tale Engelsk«. "Jeg kan ikke, jeg taler saa 
daarligt«, svarede Prinsessen hver Gang. - Etatsraaden folte sig ogsaa her son hjemme. Han blev behandlet som en gammel kær Onkel. Vi maatte alle indskrive vore Navne i en Bog, som Dronningen lagde frem. Hun forte mig hen til et lille Bord, hvorpaa der stod forskellige Miniaturer og Antikviteter, som hun havde arvet efter sine Foraldre og andre kiere Slægtninge. De havde aabenbart meget stor Vardi for hende som Slagtsm nder. ITnder Samtalen fik jeg blandt andet Indtryk af, hvor afholdt Prins $\mathrm{H}$ a $\mathrm{n}$ s havie været ved det engelske Hof. Efter en halv Times Forløb trak vi os tilbage. Baade Dronningen og Prinsesse Victoria rakte os Haanden til Afsked.

Søndag, den 16. Marts 1919.

I 4 af Regeringen til vor Raadighed stillede Biler foretog vi en overordentlig interessant Biltur til Windsor og Maidenluead. Jeg tog Plads hos Chaufforen for bedre at nyde Udsigten og fik af hende, det var en Dame, Besked om et og andet under Farten. 'Turen førte os gennem dejlige frugtbare Egne ind $\mathbf{i}$ de store engelske Parkanlag med herlige gamle Ege, som omgiver Windsor. Vi korte ind paa Slotspladsen og blev yderst høflig modtaget. Vor Ankomst var ventet, og vi blev fort omkring i de prægtige Repræesentationslokaler, hvor der var store Billedgallerier med mange fremragende Kunstvarker. Derpaa spadserede vi i Haven og beundrede den 3 engelske Mil lange snorlige Alle, der fra Haven forte ud gennem den herlige Park. Etatsraad Andersen fortalte, at han sidste Sommer havde været Gast lios det engelske Kongepar herude, hvor det levede under meget borgerligr Forhold. Fra Windsor korte vi videre gennem her- 
lige Parker og Skove til Maidenhead, hvor vi spiste Middag. Ved 4-Tiden var vi atter tilbage i London efter at have tilbragt en herlig Dag.

Mandag, den 17. Marts 1919.

Delegationen var indbudt til Frokost i den danske Klub, men Nis Nissen og jeg forvildede os i Byen og kom derfor ikke med. Klokken 5 var vi indbudt til The hos Kammerherre Castenskiold, hvor der، danske Koloni i London var samlet. Jeg stiftede her flere interessante Bekendtskaber, deriblandt med Skibsreder Sir William Petersen, som har været engelsk Statsborger i 40 Aar og betragtes som den rigeste Dansker derovre. William Petersen fortalte mig, at han havde været en personlig Bekendt af Lord Kitchener, om hvem han i en længere Samtale fortalte mange interessante Træk. Gesandten bod os velkommen. Han havde kort Tid før haft Besøg af 4 sonderjydske Krigsfanger og meddelte os det Indtryk, deres Fortælling, havde gjort paa ham. Jeg tog derefter Ordet og bragte Englænderne en Tak for deres udmærkede Bistand og for den Venlighed, hvormed de havde modtaget os. I min Tale fik jeg endvidere Lejlighed til at udtale min Glade over det stærke Sammenhold, som vi havde fundet mellem Danskerne i England, et lignende sammenhold havde vi ikke fundet i Paris. Men dette hænger maask sammen med, at Danmarks livlige Handelsforbindelse med England har skabt en fast bosiddende Koloni i London, medens Danskerne i Paris mere er Fugle paa Træk.

Tirsdag, den 18, Marts 1919.

Vi afrejste i Pullmanvogne fra London til Newcastle og gik ombord i Det Forenede Dampskibssel- 
skab's S/S "Moses Melchior". Ved 1-Tiden kastede vi los og gik ned ad Floden. Det var en dejlig Nat. Vi spadserede en Times Tid paa Iæakket og gik saa til Kojs. Ud paa Morgenen blæste det stærkt op, og da vi stod ud i Vesterhavet, havde vi en Brandstorm. "Moses Melchior" var sammenlignet "Fionia" en lille Skude som arbejcler svært i snerne. Paa de to Etatsraader nær blev vi derfor i Køjerne hele Dagen.

Torsdag, den 20. Marts 1919.

Stormen lagde sig, og Søen blev roligere. Jeg gik allerede op paa Dækket om Formiddagen, og lidt efter lidt blev Selskabet atter fuldtalligt. Ud paa Eftermiddagen fik vi Norges Kyst i Sigte. Efter at Morket var indtraadt, saa vi Hirtshals's Fyr og ved Midnatstid passerede vi Skagen. Vi passerede talrige svenske Fiskerkvaser, som havde Lanterne tændt. Fyrene blinkede, Himlen var stjerneklar, og vi saa et herligt Nordlys, som sendte straalebundter helt op til Zenit.

Fredag, den 21. Marts 1919.

Vejret var nu blevet godt. Vi passerede Anholt og gik i Magsvejr ned over Kattegat. Det klarede mere og mere op, og i herligt Vejr stod vi ned ad sundet. Ud paa Eftermiddagen naaede vi København. Da vi lob ind i Havnen, saa vi fra Darkket Kongen, Dronningen og en af de unge Prinser ved Anløbsstedet. Vi stey i Land. Kongen hilste straks paa Etatsraad Andersen og de andre Herrer, som han kendte. Etatsraaden forestillede os derefter for Kongen, som vekslede nogle ord med os. Vi tog derefter til vore Hoteller og mødtes senere i Udenrigsministeriet for at aflagge Beretning. 
Det havde været vor Hensigt at rejse hjem om Søndagen, men Fredsdelegationen blev tilsagt til Audiens hos Kongen om Mandagen. Vi blev derfor $\mathbf{i}$ Byen Mandagen over. Kongen hilste meget hjerteligt paa os og udtalte sig bevæget om sin Bedstefader og hans Fortællinger om Sønderjylland, der tidligt havde gjort et dybt Indtryk paa ham. Han udtalte overfor mig, at den Tid nu forhaabentlig endelig var forbi, da man mistænkte Kongehuset for at være tysksindet. Hans Bedstefader havde i sin Tid lidt meget under denne Mistanke. Jeg svarede, at al Mistanke i den Retning sikkert forlængst var fjelnet, og at vi tværtimod under vor Berøring mell Kongehusets Medlemmer i Paris og London havde faaet det starkeste Indtryk af den rorende Kærlighed, livormed Kong Christian IX's Born og Bornehorn omfattede Danmark. 